\title{
Detection of Antibodies against Avian Leukosis Viruses with Indirect Immunoperoxidase Absorbance Test
}

\author{
Yoshio MIZUNO*, and Hideo HATAKEYAMA \\ National Institute of Animal Health, 3-1-1 Kannondai, Yatabe, Tsukuba, Ibaraki 305
}

(Received 5 April 1982/Accepted 13 October 1982)

\begin{abstract}
The indirect immunoperoxidase absorbance (IIPA) test was used to detect chicken serum antibody against avian leukosis viruses (ALVs). Total 155 serum samples collected from chickens experimentally infected and not infected with ALV were tested by the method and the result was compared with that of the virus neutralization (VN) test. As a result, there was a high correlation $(\mathrm{R}=0.648)$ between the two. Besides, the sera of chickens infected with Rous associated virus (RAV) showed type-specificity when examined by the method. Therefore, those infected with RAV-1 were clearly distinguished from those infected with RAV-2. Then eight chickens were inoculated with RAV-1 to study the rise and fall in antibodies. In them, IIPA antibody presented almost the same rise and fall as VN antibody.
\end{abstract}

Antibodies against avian leukosis viruses (ALVs) have been estimated by various biological and immunological methods. The virus neutralization (VN) test [1] has been frequently used as one of all the biological methods. Although it is quite sensitive, it is not applicable to the estimation of accurate VN antibody titer. This is because Rous sarcoma virus (RSV) is used as an indicator in the test and because the $\mathrm{VN}$ antibody titer is dependent on the amount of coexisting Rous associate virus (RAV) [5]. Moreover, the $\mathrm{VN}$ test is able to be performed in only the limited laboratory since the technique is too much complicated. As immunological means are known the fluorescent antibody (FA) technique [8], the indirect immunoperoxidase (IIP) method [2], and radioimmunoássay (RIA) [7]. It is difficult to determine the objective antibody titers of many samples at the same time by either of the first two means. RIA is not readily applicable, since iodine-125 is used in it and fresh labelled antibody must be prepared for each assay.

In the present investigation by using 96 well plates, studies were made to determine whether ALV antibody could be estimated by measuring the absorbancy. Besides, attempts were made to detect this antibody from serum samples.

\section{Materials and Methods}

Viruses and cells: The viruses used were RSV (RAV-1) and RAV-1, both of which belong to subgroup A of the Bryan high titer (BH) strain, and RSV (RAV-2) and $\mathrm{RAV}-2$, both of which belong to subgroup B of this strain. Each RAV had been isolated from each $\mathrm{BH}-\mathrm{RSV}$ material by the end-point dilution method. The stock virus was allowed to multiply in chicken embryo fibroblast cells (CEF) susceptible to the respective virus and stored at $-80^{\circ} \mathrm{C}$. These cells had been cultured by the method previously men-

* Present address: National Institute of Animal Health 31 Uminai, Shichinohe, Kamikita, Aomori 039-25. 
tioned [1] from 10-day-old embryos originated from hens of the $15 \mathrm{I}$ and $\mathrm{BK}$ strains [5] raised in ALV-free conditions. In the present experiment, the initial culture of these cells was inoculated with 0.1-1.0 of multiplicity of infection of each RAV and incubated for 3-5 days after the inoculation. Then the cells were subcultured in a 96 -well plate to such extent that $4 \times 10^{4}$ cells might be contained in a well, and incubated further for 3-4 days. After that, they were fixed in periodate-lysine-paraformaldehyde $(0.037 \mathrm{M}$ sodium phosphate buffer solution, $\mathrm{pH} 7.4$, containing $0.01 \mathrm{M}$ sodium m-periodate, $0.075 \mathrm{M}$ lysine, and $2 \%$ paraformaldehyde) [3] on iced water for 30 minutes and subsequently in methanol for 10 minutes. Cultivation of cells was performed in $5 \% \mathrm{CO}_{2}$ incubator at $37^{\circ} \mathrm{C}$.

Serum: Chickens of the 15I or BK strain were inoculated experimentally with RAV or RSV. A total of 155 serum samples were collected from them. They consisted of samples collected at given intervals of the time, including 15 samples collected before inoculation, those collected at a given stage of infection, and those collected from chickens immunized several times. All of them were stored at $-20^{\circ} \mathrm{C}$ until use. Each sample was heated at $56^{\circ} \mathrm{C}$ for 30 minutes and diluted with B-VBS (veronal buffer saline solution containing $\mathrm{Ca}^{++}$and $\mathrm{Mg}^{++}$ to which had been added $10 \%$ bovine serum) to prepare twofold serial dilutions ranging from $1: 12.5$ to $1: 12,800$ immediately before use.

Horseradish peroxidase (HRPO)-conjugated rabbit anti-chicken IgG: Rabbit antichicken IgG was isolated by affinity chromatography completed with purified chicken IgG [2]. It was conjugated with HRPO by the method of Nakane et al [4]. HRPO-conjugated rabbit anti-chicken
IgG was stored at $-80^{\circ} \mathrm{C}$. It was diluted at 1:40 with B-VBS immediately before use.

Staining and measurement: CEF infected with RAV, as well as those not infected, were fixed in such manner as mentioned above. They were washed once with TUNEBS $(0.05 \mathrm{M}$ tris-HCl buffer solution, $\mathrm{pH} 8.0$, containging $1 \mathrm{M}$ urea, $1.5 \mathrm{M}$ sodium chloride, and $0.02 \%$ EDTA, in addition to $5 \%$ bovine serum). To them was added $0.05 \mathrm{ml}$ of diluted chicken serum per well for sensitization at $37^{\circ} \mathrm{C}$ in a $\mathrm{CO}_{2}$ incubator for $60 \mathrm{~min}$ utes. Then both cells were washed six times with TUNEBS. To them was added HRPO-conjugated rabbit anti-chicken IgG and sensitized also at $37^{\circ} \mathrm{C}$ in a $\mathrm{CO}_{2}$ incubator. After that, the cells were washed in the same manner. To them was added $0.1 \mathrm{ml} /$ well of a reaction mixture $(0.05 \mathrm{M}$ tris- $\mathrm{HCl}$ buffer solution, $\mathrm{pH}$ 7.6 , containing $0.5 \mathrm{mg} / \mathrm{ml}$ of diaminobenzidine and $0.05 \%$ peroxide) and subjected to optical measurement at a wavelength of $450 \mathrm{~nm}$ by a spectrophotometer (Multiskan; Titertek, U.S.A.) for micro-well use, with a well containing no chicken serum as a control. The IIPA index of each serum sample was expressed as a ratio of the highest serum dilution that had given rise to an absorbance unit (AU) of 0.2 (the value fixed by referring to the results obtained) between both cells infected and uninfected with RAV.

The IIPA index=

The value of the highest twofold serial

The value of the highest twofold serial serum dilutions of infected cells at

serum dilutions of uninfected cells at $\frac{0.2 \mathrm{AU}}{0.2 \mathrm{AU}}$

Virus neutralization (VN) test: The VN test was carried out by the method previously mentioned [1]. The VN anti- 
body titer of each serum sample was expressed as a reciprocal of the highest dilution that had inhibited more than $90 \%$ of the focus of RSV.

\section{RESUlts}

Reaction curve of serum measured by the IIPA method: Fig. 1 shows a curve of reaction between cells infected or not infected with RAV-2 and anti-RAV-2 serum. In the case of the infected cells, the absorbance value presented a gentle sigmoid curve, with $0.6-0.8$ as the highest values, as serum dilution advanced. In the case of the unifected control cells, this value was relatively high in a range of low dilutions, but decreased remarkably as serum dilution advanced. In general, it was below 0.1 before serum dilution reached 1:200. On the other hand, when the 15 samples of uninfected chicken serum was used, the infected cells exhibited almost the same reaction curve as

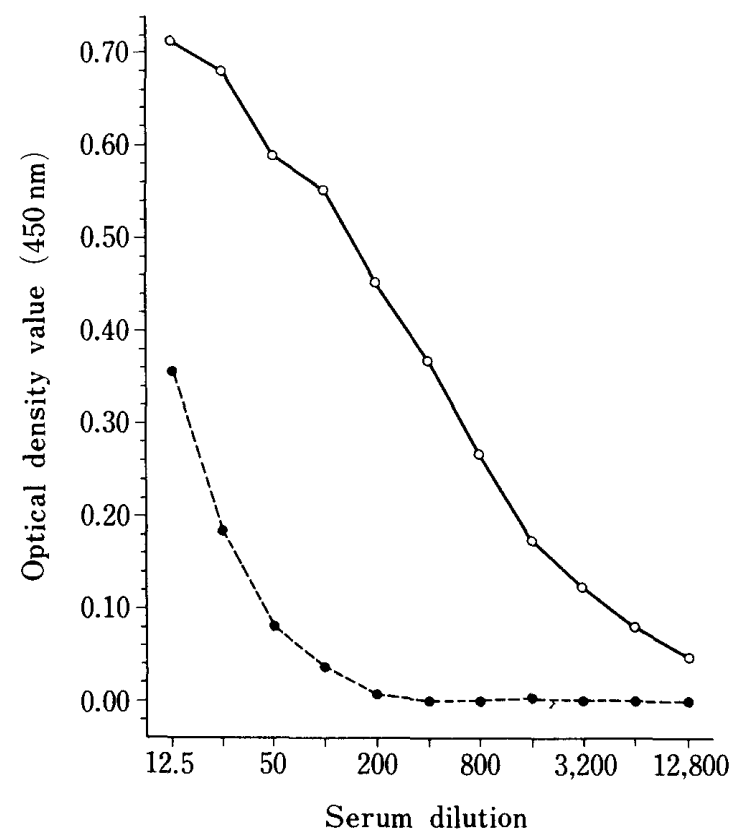

Fig. 1. Curves of reaction between serial dilutions of anti-RAV-2 chicken serum and RAV-2infected $(\mathrm{O}-\mathrm{O})$ or mock infected chicken embryo fibroblasts in indirect immunoperoxidase absorbance tests. the control cells (Fig. 2). This curve was similar to that shown in Fig. 1 and indicating the reaction between antiserum and control cells.

IIPA index of uninfected chicken serum: The IIPA index was determined in the 15 samples of uninfected chicken serum. As a result, it was $\leq 1$ in every sample. To be precise, it was 1 in seven samples and $<1$ in the other eight.

Correlation between IIPA index and VN antibody titer: The IIPA index was determined, at various absorbance values, in the 155 chicken serum samples, including 15 uninfected chicken serum samples. Then it was compared with the VN antibody titer measured in the $\mathbf{1 5 5}$ samples to clarify a correlation between that index and this titer. As a result, the highest correlation $(R=0.648)$ was demonstrated when the absorbance value was 0.2 (Table 1). Fig. 3 exhibits the correlation between IIPA index and VN antibody titer at an absorbance value of 0.2. Every sample of uninfected serum was negative for both IIPA and VN antibody.

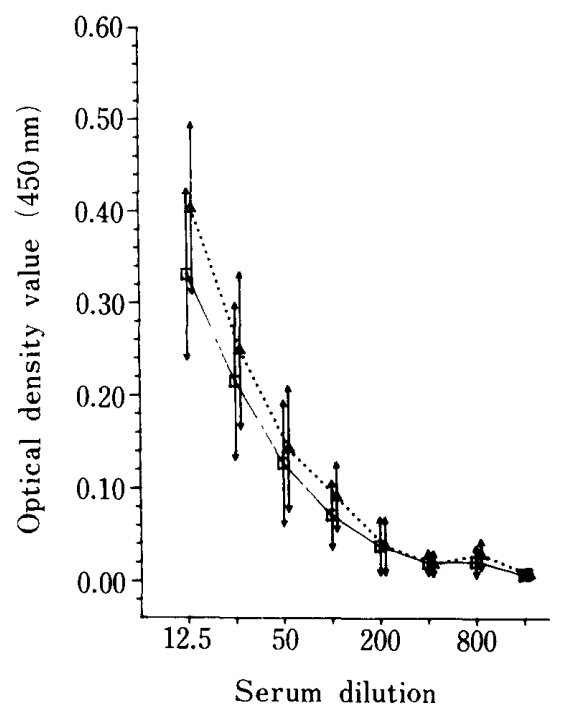

Fig. 2. Curves of reaction between serial dilutions of uninfected chicken serum samples and RAV-1-infected $(\mathrm{O}-\mathrm{O}$ ) or mock infected (----) chicken embryo fibroblasts in indirect immunoperoxidase absorbance tests. 
Many samples of infected serum, however, were positive for IIPA reaction, although they were nagative for $\mathrm{VN}$ antibody.

Type-specificity of anti-RAV chicken serum as revealed IIPA test: Both IIPA and $\mathrm{VN}$ test were applied to five and six samples selected at random from 85 antiRAV-1 and 23 anti-RAV-2 chicken serum samples, respectively. In this manner virus typing was performed. The results obtained are shown in Table 2.

Table 1. Coefficient of correlation between virus neutralization antibody titer and indirect immunoperoxidase absorbance index at various optical density values

\begin{tabular}{cc}
\hline Optical density values & $\begin{array}{c}\text { Correlation } \\
\text { coefficient }\end{array}$ \\
\hline 0.1 & 0.597 \\
0.16 & 0.638 \\
0.2 & 0.648 \\
0.3 & 0.548 \\
0.4 & 0.585 \\
0.5 & 0.526 \\
0.6 & 0.424 \\
\hline
\end{tabular}

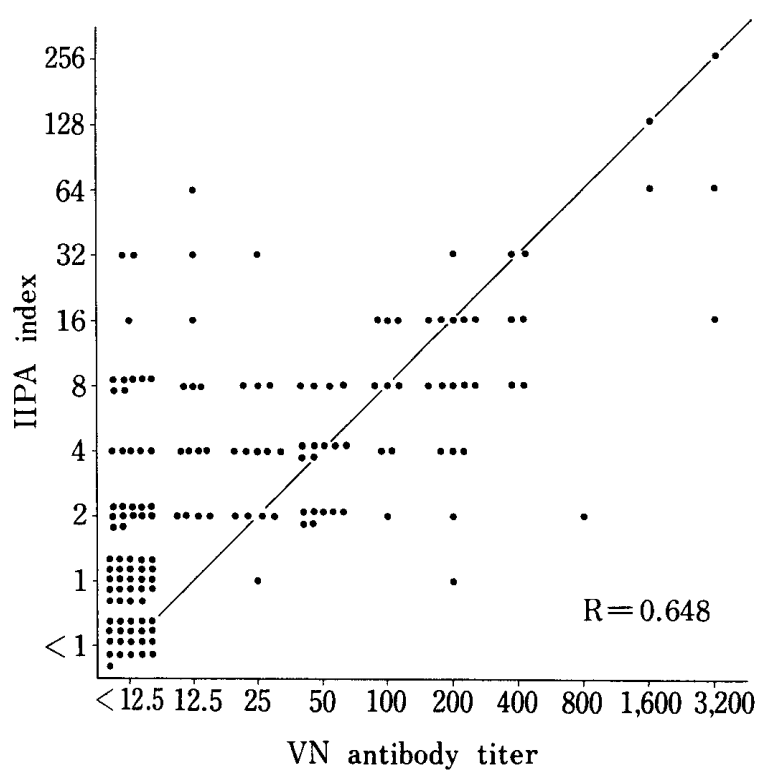

Fig. 3. Correlation matrix between indirect immunoperoxidase absorbance index and virus neutralization antibody titers.
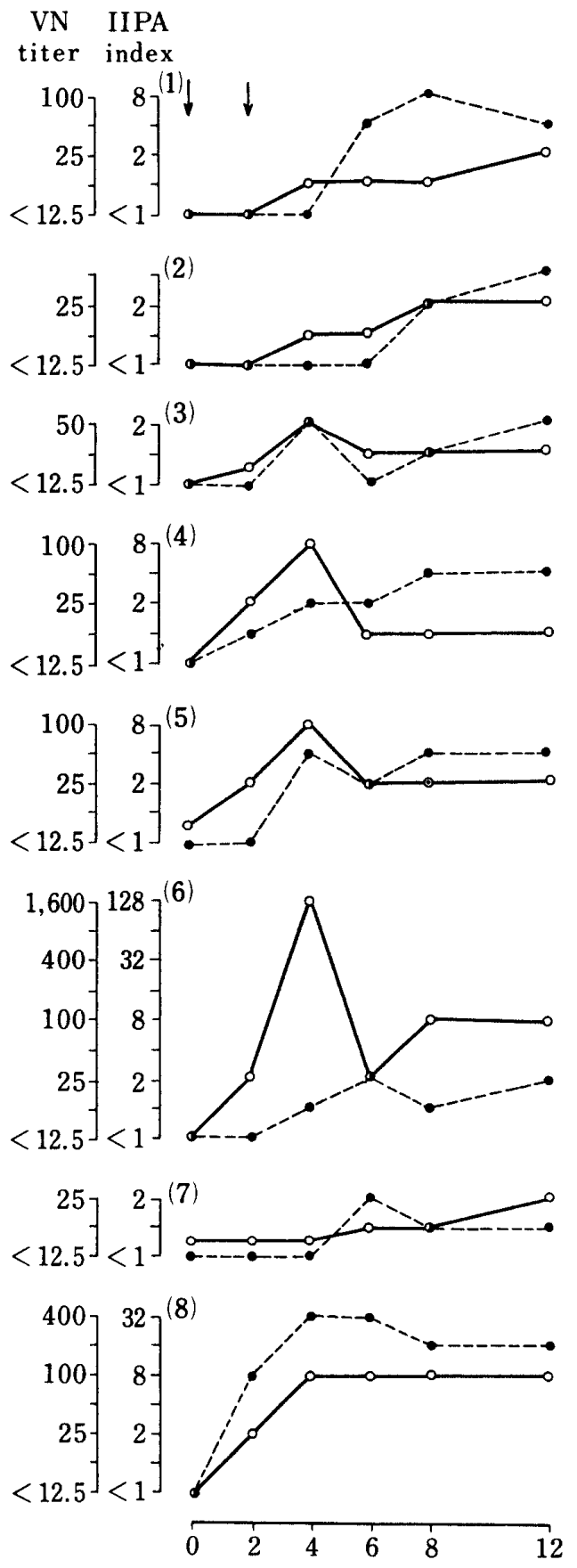

Weeks after the first inoculation

Fig. 4. Antibody responses of 8 chickens infected with RAV-1. All the chickens were inoculated with RAV-1 on day 0 and 2 weeks $(\downarrow)$ after the first inoculation. Sequential antibody titers were determined by indirect immunoperoxidase absorbance tests $(\mathrm{O}-\mathrm{O})$ and virus neutralization tests (-). The numerals, (1)-(8), indicate chicken numbers. 
Anti-RAV-1 serum reacted specifically with the corresponding virus, but did not with the heterologous type of virus. Anti-RAV-2 serum reacted strongly with the homologous type of virus and very weakly with RAV-1. The IIPA index did not always rise of fall in parallel with the $\mathrm{VN}$ antibody titer in either of the two serum groups.

Rise and fall in antibody titer: Eight chickens were inoculated intravenously with $10^{6}$ resistance-inducing units (RIU) of RAV-1. Two weaks later they were inoculated intramuscularly with $10^{7} \mathrm{RIU}$ of $R A V-1$. The rise and fall in antibody titer were examined in each chicken by the IIPA and the VN method. The antibody titer determined by the one method showed essentially the same rise and fall as that determined by the other method in all the chickens, except one, chicken No. 6 (Fig. 4). This chicken presented an extraordinarily high IIPA index temporarily.

\section{Discussion}

When observation was made on a cor- relation between IIPA index and $\mathrm{VN}$ antibody titer, there were many serum samples that showed high IIPA index but low VN antibody titer (Fig. 3). The cause is unknown for this result. The IIPA index was $\leq 1$ for the 15 uninfected serum samples, without exception. The other 140 serum samples examined were all derived from chickens inoculated with virus. Therefore, the IIPA method seems to be more sensitive than the VN method for the detection of ALV antibody. When individual samples were studies, the IIPA index was not in parallel with the VN antibody in relatively many samples (Table 2 and Fig. 3). Accordingly, it is possible to presume that the antigen discriminated by the IIPA method may be different from that discriminated by the VN method.

When type-specificity was examined in the antisera, anti-RAV-2 serum exhibited a weak reaction with $\mathrm{RAV}-1$ antigen. It is unknown whether this result was brought about from the properties of antibody against RAV-2 or from any other cause.

Table 2. Viral type specificity of anti-RAV-1 and anti-RAV-2 chicken sera tested by virus neutralization and indirect immunoperoxidase absorbance tests

\begin{tabular}{rrrrrr}
\hline \multirow{2}{*}{ No. of chicken sera } & \multicolumn{2}{c}{ VN*1 $^{* 1}$ antibody titer } & \multicolumn{2}{c}{ IPA*2 $^{* 2}$ index } \\
\cline { 2 - 5 } & \multicolumn{2}{c}{ RAV-1 } & RAV-2 & RAV-1 & RAV-2 \\
\hline & 4872 & 1,600 & $<4$ & 32 & $<1$ \\
Anti-RAV-1 & 4876 & 400 & $<4$ & 32 & 1 \\
& 5731 & 100 & $<4$ & 16 & 1 \\
& 5759 & 50 & $<4$ & 8 & 1 \\
& 5481 & 200 & $<4$ & 16 & 1 \\
\hline \multirow{4}{*}{ Anti-RAV-2 } & AA2 & $<4$ & 400 & 2 & 64 \\
& 5724 & $<4$ & 50 & 2 & 8 \\
& 5747 & $<4$ & 50 & 2 & 8 \\
& 5749 & $<4$ & 25 & 4 & 16 \\
\hline
\end{tabular}

*1 VN: Virus neutralization

*2 IIPA: Indirect immunoperoxidase absorbance. 
A nonspecific reaction is the most important of all the problems on the application of a serological test of high sensitivity. When the IIPA method is performed with TUNEBS as washing solution, it is possible to distinguish a positive reaction clearly from a reaction which seems to be negative. Non infected control culture, however, reacted with serum showing relatively high absorbance in a range of low dilution of serum. Chicken serum might have some immunoglobuline molecules which have different affinity on surface of fixed cell. Therefore, it is necessary to pay attention to the application of this method in the range of low serum dilution. The IIPA method used in the present investigation is complicated, because it is necessary to prepare a series of dilutions from each serum sample for reactions with infected and uninfected antigens. Nevertheless, it is useful to detect the antibody even in such serum as showing a rather high nonspecific reaction by this method. Besides, antigen can be stored for a long time for this method [3].

The nonspecific reaction was depended on each serum, and was varied in wide range especially in low dilution of the serum (Fig. 2). Therefore, a simple measurement of IIPA antibody titer was gotten into the risk of misjudgement. Then, the absorbancy unit as the volume of the pigment was regarded as the result of the antigen-antibody reaction, was used as indicator in this study. The IIPA antibody titer as index was culculated in com- parison between infected and uninfected cells at each dilution of the serum.

Acknowledgments. The authors wish to express their gratitude to Drs. Kono, Y. and Horiuchi, S. of the Equine Infections Anemia Research Division, National Institute of Animal Health, for their advice and review of this manuscript.

\section{REFERENCES}

1. Mizuno, Y., Yuasa, N., Hihara, H., Ishizaki, R., and Shimizu, T. (1970). Neutralizing antibody against avian leukosis viruses in abnormal chicken sera. Bull. Natl. Inst. Anim. Health No. 60, 1-5.

2. Mizuno, Y., and Arai, K. (1981). Assay of avian leukosis viruses by indirect immunoperoxidase method. Natl. Inst. Anim. Health Q. 21, 63-67.

3. Mizuno, Y., and Arai, K. (1982). Stability of avian leukosis virus type specific antigen in the cell after fixation in periodate-lysineparaformaldehyde. Natl. Inst. Anim. Health Q. 22, 34-35.

4. Nakane, P. K., and Kawaoi, A. (1974). Peroxidase-labeled antibody. A new method of conjugation. J. Histochem. Cytochem. 22, 1084-1091.

5. Rubin, H., and Vogt, P. K. (1962). An avian leukosis virus associated with stocks of Rous sarcoma virus. Virology 17, 184-194.

6. Shimizu, T., Ishizaki, R., Hihara, H., Mizuno, Y., Sazawa, H., and Sugimori, T. (1968). Development of a chicken flock free of avian leukosis viruses. Bull. Natl. Inst. Anim. Health No. 57, 9-15

7. Smith, E. J., Crittenden, L. B., and Ignjatovic, J. (1977). Comparative study of three methods for detection of avian leukosis viruses. Infect. Immun. 16, 500-504.

8. Vogt, P. K., and Rubin, H. (1961). Localization of infectious virus and viral antigen in chick fibroblasts during successive stages of infection with Rous sarcoma virus. Virology 13, 528-544. 
要 約

間接免疫ペルオキシダーゼ吸光法による鷄白血病ウイルス抗体の証明：水野喜夫, 畠山英夫 (家 畜衛生試験場)一一間接免疫ペルオキシダーゼ吸光 (IIPA) 法を用い, 鵴白血病ウイルス (ALV)に 対する鶏血清中の抗体の検索を行った。総計 155 例の ALV 実験感染抢よび非感染血清について IIPA と中和試験による抗体価の比較を行った結果, 両者の成績の間に高い相関関係 $(\mathrm{R}=0.648)$ が認められた。さらに, Rous associated virus (RAV) 感染例の血清抗体は中和抗体と同様, 型 特異性を示し, RAV-1 感染例は RAV-2 感染例と明確に区別できた。また，8羽の鷄に RAV-1 を接種し，抗体の消長を追ったところ，IIPA 抗体は中和抗体とほぼ同様の消長を示した. 